\title{
The Visible Flâneuse in Chan Ling Yap's Where the Sunrise is Red
}

\author{
NURUL ATIQAH AMRAN \\ Department of English, \\ Faculty of Modern Languages and Communication, \\ University Putra Malaysia \\ atiqah.ariff88@gmail.com \\ ARBAAYAH ALI TERMIZI \\ Department of English, \\ Faculty of Modern Languages and Communication, \\ University Putra Malaysia
}

\begin{abstract}
Malaysia's historical image in literature has almost always been exotically depicted. In some parts of literary works, geographical and physical settings serve merely as a literary device. The overwhelming depictions of characters' geographical movements and relationship with their cities in the novel, Where the Sunrise is Red sparks the current resurgence to explore the visibility of the female protagonists in terms of their representations in the public sphere. Thus, the extent to which their representations are central to the development of the narration is debatable and to understand this; we must take into consideration Baudelaire's construction of European urban figure, flâneur, emphasising the female version, the flâneuse. Different locations in colonial Malaysia and England seem to be the manifold literary device with which Yap develops her plots, yet the focus will be only at the crucial public domain that invites stares, barriers, and perceptions through the eyes and feelings of the character. Besides emphasising the characterisation of the protagonist, this setting is also symbolic of the underlying themes in the novel. The various public spheres where the protagonist is physically and visibly connected depict the reconstruction of a flâneuse in Malaysia's historical representation in literature. Hence, the objectives of this study involve identifying the role of the public sphere and elaborating how these settings serve as the platform for flâneuse's visibility in the Asian context through characterisation, physical setting, and symbols in the text.
\end{abstract}

Keywords: flâneur; flâneuse; public sphere; historical fiction; Malaysian literature in English

\section{INTRODUCTION}

The public sphere has always been regarded as an exclusive space for men. The European society in the eighteenth century until the early twentieth century believes in the idea of sexual divisions by giving exclusive space for men to conquer the public domain while women dominate the private sphere. It has also been portrayed in the 'romantic' depictions of a fláneur as an invisible figure of the city in the nineteenth century Paris by Charles Baudelaire and Walter Benjamin, yet very little attention has been made to acknowledge the existence of a female version of a fláneur. Elkin (2016, p. 10), in her findings, examine that across critical discussions such as in politics, education, and economics, women's visibility and involvement in the public platform are largely missing. However, the political movement raised by feminist groups in the European setting has planted a solid foundation to change this gendered landscape and influenced women in other parts of the world.

For both of them and for all those who witnessed the Malay nationalist movement in those days the most remarkable feature was the part Malay women played. They were challenging, dominant, vehement in their emergence from meek, quiet roles in the kampongs, the rice-fields, the kitchens, and the nurseries. In Kuala Kangsar, where the U.M.N.O. had arranged the biggest demonstration, even the wife of the Sultan of Perak headed a mile-long procession of protest past a dais on which sat all the Malay Rulers, the Parliamentarians, and Onn.

(Miller 1982, p. 81) 
This quote from "Prince and Premier: A Biography of Tunku Abdul Rahman Putra" (Miller 1982) depicts the situation that transpired during the British colonial period in Malaya. It implies that the colonial city of British Malaya at that time was not a space-limited merely for men. During pre-Independence Malaya, women had actively participated in the nationalist movement. From being perceived by the colonials as timid, muted, and invisible who dominated rural areas, paddy-fields and domestic spheres, these women, particularly Malays, played crucial roles in the nationalist movement. The 'mile-long procession of protest' (Miller 1982) which involved both women and men during that era indicates how the act of walking "contributes to the making of space" as suggested by Ceuterick (2020, p. 96). Indeed, the street's activities in which these women participated rendered different meaning and status in the Malayan context. It did not only suggest that women had been given the capacity to challenge their traditional role, but the conquering of the public sphere empowered Malayan women and that they too can become, following Ceuterick description, "normal inhabitants of the public space" (p. 96). The exploration of public space by women in Malaya during that period; however, did not represent the total gender and racial population at that time. From the quote above, it can be seen that Malay women were the dominant group who supported the nationalist movement in Malaya. In fact, as the earliest occupant of Malaya and the primary leaders of the states, Rizal Yaakop (2014) argues, that was the reason Malays were very vocal and significantly affected by the British intervention that transformed the demographic and political geography of Malaya (p. 56). However, Mohamad observes there was equal participation in the nationalist struggles by the three major races: Malays, Chinese and Indians (2002, p. 83) especially after the Japanese occupation. The traumatic period led to greater political awareness and radical nationalist movement in society. The resistance towards the colonial power had moved the entire nation and thus, contributed to the participation of women from different races in the public sphere.

Nevertheless, the participation of women in the city or the public sphere appears inconsistent with the traditional Parisian flânerie considering the context of the time, geographical landscape, and political situation during that era. As walking in the urban sphere from the context of the nineteenth-century Paris connotes the existence of male domination and limited female access in the public facilities, we are moving beyond this reception of Benjamin's dominant European-centred model that extends the continent and cultural horizon. In Malaysia's history, the period during Japanese occupation has been considered, according to Mohamad (2002) as the significant event that had ruined British supremacy and the people's trust, causing not only the male nationalist movement but also igniting feminist emancipation to appear in the public matters and spheres (p.83). Some of the political parties established for both Malay women and non-Malay women during that era were mobilised for women's participation though it was still directed by men. The establishment of a new platform in public for women allowed them to take up the non-traditional roles that were once deemed unfit for them. Besides, men saw this as one of the political strategies to mobilise the majority of the population in Malaya. However, due to its radical movements after the return of British colonial rule in Malaya and pro-Japanese influences that challenged the resumed control, the rise of these groups were thwarted by the British and eventually disbanded (p. 84). United Malays National Organization (UMNO) was established by the British to tame the radical nationalist group and to establish their pro-British party among the people. However, it was not welcomed by the majority. While Malays were combating against the new nationalist party, the non-Malays primarily immigrants from China and India remain loyal to their original homelands. Mohamad (2002) writes that Chinese and Indian women were moulded through the education system that followed the nationalist spirit in China and India. Therefore, the system enables women to participate in the political movements that were fought in their respective homelands. The participation of women in the men's public sphere in Malaya gives 
us a hint at the existence and the visibility of the flâneuse figure in the Asian context, specifically British Malaya. Though the act of flânerie and the figure of flâneuse in the selected novel contradict to the traditional French flâneur or Baudelaire's figure of modernity, there are, in fact, many physical and verbal expressions that can be measured which describe urban walking and connection with the surroundings in the Malayan context.

Yap Chan Ling, a Malaysian born writer who currently resides in the United Kingdom, has published five novels which have been highly praised for their imaginative re-creations of Malaysia during its turbulent periods. "Where the Sunrise is Red" (2018) is the fifth novel set in Malaya in its gloaming years as a British possession and the period during the Emergency. Yao claims that the government was in "a state of confusion" when the Emergency was announced (2016, p. 42). The Malayan Communist Party (MCP) instigated extreme resistance and turned to armed resurrection throughout Malaya, thus pushing the government to control through declaring the Emergency. Yap unremittingly returns to history during the turbulence period in Malaya in all her five novels, reminiscing the old Malay land and reliving the dark experience during the challenging period. The selected novel for this analysis tells a story of a country where political tensions and tragedy jostled, in which power, status and wealth were the prerogatives of white adult males that two main female protagonists empowered one another and found true meanings in their life to rekindle hopes and love in metropolitan England and tropical city of Malaya. The twisted fate of two characters set apart by their race, class and geographical boundaries develops into tension and tragedy that intertwine their destiny. The novel is divided into three parts; each part is narrated in different time settings which cover different geographical locations involving two main female protagonists; May Anderson and Ruth Lampard. As opposed to the male-dominant contexts served in history, Yap's historical rendition engages female characters in an active network of social relationships and finds ways to appear in the public spheres set in colonial Malaysia and England in the 1950s to 1960s. In this novel specifically, Yap deviates and foregrounds the fictive world, as suggested by Zohreh \& Seyyed (2014, p. 157), into this historical fiction which attests criticism on the "notion of change and progress, especially in the lives of the marginalised and suppressed" members of the society chosen to be addressed in the fiction. Through reading the novel, readers would be overwhelmed by the movements of the characters and changes in the narration in different geographical locations. However, the appearance and visibility of the female protagonists draw significant concerns in their representations in the public sphere. Thus, the extent to which their representations are central to the development of the narration is debatable and to understand this, we must take into consideration Baudelaire's construction of European urban figure, flâneur, but emphasising the female version, flâneuse. Different locations in British Malaya and England seem to be the manifold literary device with which Yap develops her plots, yet the focus will be only at the crucial public domain that invites stares, barriers, and perceptions through the eyes and feelings of the character.

\section{AIMS OF THE STUDY}

Geographical and physical settings are the primary literary device, drawing our attention to the physical movement and the character's emotional responses. Apart from providing lucid Malaysia's historical image in literature, the public sphere involved such as in Kuala Lumpur, and London are used as a reflection of May Anderson's feelings towards the place and treatments that she receives from the surrounding elements. The first part of the novel tells stories of May Anderson who is treated and subjected to the gloomy and bleak natural landscape of Malaya during the Emergency period, disclosing a sense of danger to the character. Nature serves to be the setting that attracts danger, fear and increases unpleasant 
feelings. The existence of the character in the natural landscape exposes her to many possible threats and only makes her feel emotionally and physically affected. Thus, we omit the first part of the novel and give emphasis to the urban sphere where the character publicly existed and the development of a flâneuse through flânerie is anchored through the interaction that she makes with the surroundings in the public domain.

Ke Wang and Rui Shang $(2019$, p.409) stated that the role of a city is at its peak in the present days as compared to the situation in the past when cities were not as much as economically, politically and socially affected. However, it is important to be noted that there is a relationship formed between cities and the city inhabitants. Cities and public spheres of Malaya and England are being highlighted predominantly in the second and third parts of the novel. May Anderson involves physically and emotionally in the public domain. Her visibility is viewed and observed through her physical movement and also through the eyes of the public denizens. Besides emphasising the characterisation of the protagonist, this setting is also symbolic to the underlying themes in the novel. The various public spheres where the protagonist is physically and visibly connected depict the reconstruction of a flâneuse in Malaysia's historical representation in literature. Hence, the objectives of this study are presented through identifying the role of the public sphere and elaborating how these settings serve as the platform for flâneuse's visibility in the Asian context through characterisation, physical setting, and symbols in the text.

\section{LITERATURE REVIEW}

Flâneur is a French word that is closely associated with the nineteenth-century to the early twentieth-century urban experience. The figure of flâneur emerged simultaneously during the industrial revolutions in England and Paris which brought important shifts in the way critiques and scholars view the participation of wanderer, idler, walker or observer to the cultural, social and architectural landscape of the western metropolis. Furthermore, it was Charles Baudelaire and his works that provide further elaboration and interpretation, which closely defined the nature of the flâneur. In his essay, "The Painter of Modern Life" (1863), a flâneur is being characterised as male, private, possesses the luxury of time and money, artistic and is driven to observe the public life in search of meaning but remain aloof from the crowd (Coverley, 2012, p.154). Flâneur which is derived from the French verb flâner is invariably seen as male (Coverley, 2012, p. 153) that he belongs solely to the European streets and he offers new ways to explore and experience the city, unlike any other city inhabitants. In Boutin (2012, p.124), flâneur is identified as a "fashionable male idler, a leisurely stroller, an expert reader of urban signs, an artist or writer, and a sociologist with the city which he is associated." He is portrayed as a figure who connects with the city, memorises the street, and every path he takes that brings him into an abstracted state of absorption. He walks without a purpose, yet he leaves marks, collects the remnants or objects captured through his senses from the corner, alleyway, and stairway and connects with his emotions. Boutin (2012, p.132) discusses flâneur (the walker) and flânerie (the action of walking), acknowledging the inclusion of sensory to this activity, and claiming that the urban landscape possesses the sensuous joy that drives flâneur to the urban sensations and plunge him into reverie. The multitude of sights, sounds, smells, tastes and touches that flâneur experiences derive a distinctive social classification between race, gender, urbanisation, industrialisation, colonialism within private and public spaces. The flâneur's persona has led to its adaptation and transformation far beyond European boulevards and arcades transcended the originality to give more patterns on whom to observe and how to walk in the city. 
Popularised in the writing of Charles Baudelaire, this literary figure has been linked to the urban experience intended to understand the meaning of life in modernity. Dana Brand (1991) in Malone (2012, p. 84) argues that flâneur is traditionally gendered and defined by its geographical marker. To locate flâneur in another metropolitan city such as in America or Asia, the traditional cultural component of flânerie from Paris and London complicates such an attempt. The problems arise due to the location of the city landscape, which deviates from the European standard in size and scale and offer different spectacle and vastness needed by the flâneur and activity of flânerie. Though American cities in the nineteenth-century were primarily in the process of urbanisation and some cities were regarded as modern and advanced following the sprawling cities in Paris and London, American metropolises lack the essence of flânerie for the flâneur to enjoy wandering and observing due to their limited spectacular space required by flâneur. Bautista (2017) views the representation of American cities through the eyes of an American flâneur in Prince's musical figures. Moving beyond the typical geography of the flâneur, Prince highlights the physical mechanism of the American cities that he associated with his songs. Bautista traces Prince's songs as conjuring the metropolitan that is tainted with gender discrimination, racial bodies and class privilege (p. 363). Another image of the American city that has been compared with France is through the association of cultural identity. Dwyarie and Tjahjani (2019) explain this further in their comparative analysis of French and American culture where the former is being described in abstract forms related to art, intellectuality and knowledge. Meanwhile the latter possesses elements of concreteness, wealth and fame of the people in it. Thus, this strengthens Bautista's findings in Prince's depiction of the American cities where underneath the wealth and fame of the city, there lies the social problem of the urban citizens. However, cities in Asia were entirely experiencing different kinds of urbanisation in that era. Several parts of the country developed rapidly due to the mining activities and others emerged after the war. They were mostly affected by the colonisation, war and post-war political conflicts. Therefore, the Asian cities' landscapes also do not correspond to the ideal flânerie essence. A wanderer or street observer in the Asian cities are not in agreement with the ideal Parisian or Londoner social deviant, an idler who does no real or tangible purposes. However, these limitations provide an opportunity for critics to explore the possibilities of a flâneur to experience urban wandering in different geographical landscapes in different countries. The current century has seen a rapid development of globalised cities, including in Asia and provided a platform for the contemporary act of flânerie. The discussion on Asian flâneur has brought together several critics such as Chaudury \& Lundberg (2018), Elkin (2017), Ruzy \& Fatin (2016) and Hahn (2014) to approach flâneur and Asian cities namely Singapore, Tokyo, Kuala Lumpur, and Bombay in contesting the traditional idea of flânerie or the act of walking in the city. According to King (2008), Singapore is the leading post-colonial city in Southeast Asia and preceding the standards of many other modern capitals such as Kuala Lumpur and Penang. In this era, Singapore is undergoing rapid development in building creative Asian city; hence, Chaudhury and Lundberg (2018) suggest that flânerie as part of the ethnographic tools to observe and engage in the creative city at the ground level. Meanwhile, in Tokyo, Elkin (2017) describes the place as a non-walkable city. The city landscapes are not wanderer-friendly with its big neighbourhood, and some parts are connected with long pedestrian-unfriendly highways (p.151). However, with the limited access and space that the city provides, she finally began to appreciate the strange elements in the Tokyo streets. Kuala Lumpur in Ruzy \& Fatin (2016), is described as a city that lacks compassion and benevolence towards its dwellers. The discussion was derived from the reading of Nassury Ibrahim's selected poems, where they argued Kuala Lumpur had lost the quality of life. As the poet goes on a physical and mental journey across the urban areas of Kuala Lumpur, he figured that the city had been inflicted with severe social illnesses such as urban poverty, poorly maintained development, hostile neighbours and spiritual famine of 
its people. The poems used in this reading are unique in a way they are borne out of the experience of the poet as a flâneur in the tropical Asian city of Kuala Lumpur (2016, p. 165). The study on Malaysian landscapes has also been done by Uma and How (2019) covering the state of Kedah, city of Kuala Lumpur and Putrajaya, analysing a symbolic political representation in a Malaysian short film. This finding has shown us that the representation of Malaysian landscape connotes various thematic concern in the art and literary context, making it possible to explore it from different angles. Making close reference to modern European flâneur literature, Hahn (2014) finds that the familiarity of a city like Bombay resonates with the memory and characters of the flâneur even after sixteen years living far apart. Flânerie in this analysis is a cognitive act that aids the recognition and perception of a familiar environment. Through flânerie, Elkin (2016) explores cities in Paris, New York, Tokyo, Venice, and London. Chaudhury \& Lundberg have also shared the flânerie experience in the creative Asian city of Singapore that offers a method to observe and engage creatively (2018, p. 87). Regardless of the limited connection with the European boulevards and arcades, cities in other regions can be explored, providing there are platforms for the flâneur to wander in the urban spheres. The observation made by this urban figure with the cities offers a key to the urban experience and identity.

The significant hallmark of modernism customarily foregrounds male roles while marginalises female contributions. Elkin (2016) and Wolff (1985), for instance, find limited feminine attributes in the era where men dominated the capital city of Paris. In the European gender construction of the nineteenth-century, women were the invisible figure of modernity, and in many parts of the dominant public space, they were treated as erotic commodity items by and for the men. Adding to this construction, women from the higher social hierarchy were confined in the domestic sphere, and they could only enter the male spaces if chaperoned by companions, travelled by carriage or disguised in men's attire. Elkin found this has been depicted in the scenes of "Madame Bovary" and in the diaries of Marie Bashkirtseff (2016, p. 12). Furthermore, women who are found to occupy and roam in the street were subjected to be identified as a prostitute and insignificant identities such as an old lady, a widow or a street seller (Elkin, 2016 \& Wolff, 1985). However, they did not enjoy the free-range over the city space. Women's movements in the city regardless of their social class were strictly controlled and defined by men. Sayyed and Tayyebeh (2018) also problematise women's conflicting roles in the period during women's liberation movement where they are pushed to embrace their invisibility in the social sphere that has been constructed by the system of patriarchy (p.163). Esmaeil (2019) adds that "this imposed invisibility and enforced reticence in a patriarchal society turned women into a social non-existence figure" (p. 116). This evidence showed that the liberty to roam the street was not given to the women; the city space was dominated and ruled by men. Therefore, gender and class are some of the most defining elements in the modernisation of western metropolis. To further investigate this, we look at the nexus between humans and the city in the act of walking and bring together the socio-political context of the selected literary text. In linking these urban spaces with a flâneur together, we strive to look beyond its original pattern. From being a male-dominated space and merely a male-oriented view of the city and life, we observe how a flâneuse reclaims the public sphere dominated by men through the act of flânerie during this period, giving new form(s) in resisting gender norms generated by power as suggested by Sayyed and Tayyebeh (2018) in the public space occupied by them. Irregularities in social standards assume significant changes in the subject's identity (2018, p. 172) thus, corresponding to Elkin's (2016, p.7) approach of converting the masculine noun, flâneur, to flâneuse. This study is also acknowledging the significant contribution of female idler or observer and the connection they make with the rural and urban sphere they encounter. It seeks to explore the visibility of flâneuse in two different geographical landscapes mentioned in the novel. 
Flânerie is regarded as a thinking tool which is mostly found in the works of the Situationist International (Lucas, 2004). The basic ideas came from the theory of the dérive that explains how a person during a certain period abandons his or her usual motives for movement, work, relations with other people and entertaining activities, and letting the mind drawn by the attractions of the surroundings. This movement from one place to another helps a person's mind to creatively immersed in the surroundings by connecting their psyche with every step the person takes on the journey to explore the city. Dérive is the walking strategy used by the Situationist International as a form of action or a tool to discover knowledge, particularly in the European context. However, according to Richardson (2015), in her introduction, the discussion does not limit to British territory. The walking can also be done in many other cities around the world, including taking a stroll in the rural area or nature-based location. Coverley views the writer is also a walker and that he distinguishes different types of walking to understand the complex art of the physical movement which affects the individuals and also how the action is drawn by the context of the surroundings (2012, p.11-16). Walker is regarded as a philosopher which connects with the history of the peripatetic philosophers who claimed that the rhythms of the body while walking resonate in the thinking process (p.22), walker as a pilgrim is achieved through which one's movement is made to reach the sacred goal after achieving a balance in thought and action (p. 39). Coverley also views the act of imaginary walking based on the practice of armchair travel where the imagination as a traveller transports beyond the boundaries of time and space (p.61). The imagination allows the walker to escape momentarily from his or her confinement. This type of walker is evident in Tan Twan Eng's novel, "The Garden of Evening Mists' (2012) where the protagonist's sister escaped in her imagination about the Japanese garden while being tortured by the Japanese in the concentration camp. She imagines herself walking in the garden and enjoys the beauty in it, which helps her to escape from the painful reality. This form of travelling as Coverley views introduces the world with a new platform for pedestrian and armchair traveller to meet (p. 63). Furthermore, a vagrant walker is someone who walks from one place to another without a purpose. It was deemed illegal and was stated in the Vagrancy Act 1824 because this random walking creates suspicions and possible threats to the private sphere. (p. 77). However, this type of walker inspired significant movement in the eighteenth and nineteenth centuries, especially by the Romanticist as it implies "notions of freedom, both politically and aesthetically" (p.78). A walker is also connected with nature. This idea gained popular supports in the final decades of the eighteenth century because critics started to change the way they view natural landscapes from unrewarding to something spiritual and liberating. The foundation of this shift can be found in the British context of nature travelling where the traveller engaged with the untamed British countryside and admired the landscape such as in William Wordsworth's poetry (p. 102). Coverley finds that while the act of walking and connecting with nature was being enjoyed by the Romanticists, they were also drawing the dark sides of urban London providing an image of mysterious and labyrinthine (p.127). The emergence of flâneur as the ideal image of modernity debunks the claims made earlier by the nature walker. Baudelaire created this ideal figure to fulfil a dream of walking in an ideal city in his literary works. As the city has transformed its shapes, became alien to its inhabitants and restrained spaces for movement during the Haussmann's major configuration, flâneur appeared as a figure who lived an unencumbered life in the urban streets (p. 160). Coverley contends, "walking-takes a pivotal role, a means through which human beings learn to understand the world about them as they pass through it, and the traces they leave behind are recorded" (2012, p. 12-13). Nicholson (2010, p.17) views walking as a way of exploring, accommodating and experiencing the surroundings with a feeling at home. Moving on foot is one way for marking territory, in finding oneself in a new place in which driving or moving by any type of transportation do not provide. 
Furthermore, as walking plays a crucial role in mapping the world across time and space, critics almost always associate this act with men's significant participation and contributions. One of the examples can be seen in the emergence of the avant-garde movement in Paris. This revolutionary group made up of writers and artists introduced male prominent and radical walkers such as Guy Debord who popularised psychogeography, Charles Baudelaire who celebrated the male literary urban figure and Walter Benjamin who further explored the relevant passage that male has taken in conquering European boulevards and arcades through arts (Coverley 2012). The literature of modernity describes the critical experience of men in the urban milieu. Therefore, women critics such as Elkin (2016) and Wolff (1985) find that women are invisible in the literature of modernity, reclaiming only the private and secluded space which men portrayed as insignificant. As much as Nicholson (2010, p.38) insisted on walking to help keep him sane, a female idler also needs to lose in the city and help her mind to be at ease. However, there are consequences of the actions she made. For her to be visible and vital in the city walking down the street and observing the surroundings, she must deal with male observers, and some might need to face and experience street harassment. However, it depends on the perspectives one believes. In Elkin's discussion on a picture of a woman walking in the street in Florence, critics argue that the woman in the subject had to deal with the male gaze because eight men on the street surrounded her with different looks and gestures. Nevertheless, in an interview with the woman in the picture, she claims that she did not experience street harassment and for her, the picture is not a symbol of gender molestation; instead, she was enjoying her freedom when the picture was taken by a female photographer, symbolising a woman having a wonderful time (p. 285). The picture defies traditional expectations that women are far too often labelled as objects of the male gaze, signifying a space in which women too can claim their public sphere.

\section{READING FLÂNEUSE IN MALAYA AND ENGLAND}

In this discussion, we highlight four different elements to read the flâneuse, bolstering our point that the protagonist achieves visibility in the historical narration. The first element that we focus in the analysis is the setting that includes both geography and time, serving as the backdrop in the novel. Two historical periods play crucial time settings in this novel; the Malayan Emergency period and post-Independence period. According to Yao, it has been marked in history by experts that 1948-1951 as the period of the Emergency in Malaya (2016, p.43). The Malayan Communist Party (MCP) who fought against the Japanese found themselves uneasy with the British authorities. As the British recorded a bad image in assisting Malaya during the Japanese occupation, it further led the MCP to take up arms and immobilised the government after the Japanese surrendered and the British returned to Malaya (p.43). Yao also stated that the British deployed police and Commonwealth troops to strengthen the grip at the countryside as MCP mostly occupied the jungle and rural area where they enjoyed support from the Chinese rural population. This shows how the Chinese protagonist that is represented in Yap's novel finds access to the rural landscape and urban sphere in Malaya at that time. Contrary to the western cities, the pace of urbanisation in post-colonial cities faced slow and steady growth. However, the increasing population in the city centre was at the fastest rate with new government relocation policy that might have enhanced rapid development, especially in urban areas, including Kuala Lumpur. This has allowed mobilisation of people from rural areas to the city and increased social and economic change in the new developing post-colonial city. The second setting is the place, location, and space where the protagonist walks, observes or being observed, allowing herself to dwell or react to the surroundings. The emphasis is given to the public sphere in Malaya and England in which the main protagonist makes a connection. 
However, not all places will be mentioned in the analysis as we only focus on the third element, which is, flânerie. Through this particular physical movement, we could highlight protagonist visibility in the public sphere. May Anderson is a Chinese protagonist who is the main flâneuse that we study to understand various activities of walking that she commits in the narration. The omission of the British protagonist is purportedly done because she is not central to the understanding of the complex configuration of visible Asian flâneuse that we wish to investigate. This study utilises a textual analysis of the novel, Where the Sunrise is Red. It involves examining the public sphere as the setting that functions as a literary device and paying attention to the relationship that is created between space and character, as addressed and suggested by Yap.

\section{DISCUSSIONS}

The appearance of May Anderson in the urban sphere of Malaya begins later in the narration after several tragedies that she faces in the rural state of Tanjong Malim. Sundareson (2014) reported that during the Malayan Emergency, the town was a hot spot for many dreadful episodes due to the widespread violence and acts of sabotage. Though May Anderson finds ways to enter and exit the dangerous route in the jungle in search for the missing of Mark Lampard, she is not excluded from being abducted and beaten by the terrorist. This part of the novel reveals Yap's representation of the natural world that adds to the aesthetical value of the dark episodes in Malaysia's history.

May Anderson moved to the city in the second part of the novel. From a maid who served her British master, Mark Lampard, in Tanjong Malim during the Emergency period, her status changes after she marries Hugh Anderson, a British Commissioner. This identity, being associated with Anderson, has given her a new status to be visible in the public sphere:

\footnotetext{
Threading through the sacks and baskets of goods on display she made her way across the road to the Central Market, a cavernous building that housed the biggest array of fresh food stalls in any single outlet in the capital city. The heady scent of fresh fish, vegetables, fruits, meat and flowers hit her the moment she stepped into the market's interior... she headed back to the opposite side of the street and went into a coffee shop. It was crowded with shoppers enjoying cups of coffee and tea and a late morning snack. Steam rose from a stall plying fresh spring rolls stuffed with fine strips of Chinese turnips, crab meat and prawns. Another stall was churning out flat rice noodles fried with a glistening black sauce, bean sprouts, prawns and cockles. "See ham char kway teow," yelled a lad no older than ten years. He ran barefooted between the packed tables ladling out plates of noodles. The air was filled with the smell of garlics and soya sauce.

(Yap 2018, p. 162)
}

From the excerpt above, through May's eyes and flânerie, Kuala Lumpur is narrowed to the local markets, represented with the smell of the local food, various scents that invite her to go deeper into the busy street, selling domestic items familiar to women of her status and age. She changes her direction, observes her surrounding with her senses, and remains intact as she identifies with the aromas of local food that fill the street while moving in the crowd. May is a part of the crowd, but she remains aloof, distancing herself from the street shoppers and the crowd occupying the market. She is a flâneuse who are a part of the crowd but only establishes a connection with the crowd for domestic consumption. This is the traditional role occupied by the Malayan women of certain social status. During that period, domestic maids or women who came from middle to lower social class were considered responsible for handling the domestic matters outside the house. It is a perspective that Răşcanu (2018) shared, women, are typically "assumed to be the bearer of culture and the responsibility to take care of the private space" (p. 225) lies on women. Women who came from higher social class like May who is the wife of a British Commissioner were deemed unfit to enter the local street and took 
the dirty job as it is stated in the novel, "Although Hugh had asked her to leave the food shopping to the maids, she had decided she would do it herself. It gave an excuse to see Fu Yi" (Yap 2018, p. 163). May Lampard brings herself as a flâneuse, who enters the city for a purpose. She enters the marginal areas where the public view as unfit to her status as a wife to a British officer. She is also challenging the higher class status, in which she does not enjoy the luxury of having a domestic helper to assist with the domestic matters and a driver who can chaperon her wherever she wishes to go. May, in this narration, has also established that women in Malaya are a part of the urban landscape. The connection that May demonstrates between herself and the activity of food shopping is equated to what Wolff (1985) and Ferguson (1994) identify as women having close associations with economics and consumption.

The Asian woman who is a participant in public life which Yap depicts is equated to a figure of some suspicion, identified by Elkin as, "upper-class ladies" who "displayed themselves in their open carriages or took chaperoned constitutionals in the park" (2016, p. 12). As an upper-class Asian woman who is married to a British officer, characterised by periods of colonisation, Yap is making a distinct social status for May when Yap describes that May travels by car, accompanied by her designated driver:

At the other end of the town, May was equally unsettled.... The thought unnerved her. She settled
back into the seat. The car accelerated smoothly out of Chinatown, leaving the hustle and bustle
behind. She wound down the window. The air had cleared. A warm breeze blew in, bringing with it
the scent of lush vegetation. Ahead a building rose by the wayside.
(Yap 2018, p. 169)

Flânerie in the men's world is depicted as an act of leisure strolling without aim, and the flâneur abandons other purposes to observe his surroundings (Coverley 2012, p. 153). Nevertheless, Yap's flâneuse in this novel takes walking as a means to maintain contact with the living world and with other human beings. As stated in the excerpt below, May takes the act of walking with her son to provide comforts for others, a pleasure of space and time enjoyed by Ruth and May as mothers. Coverley suggests that "a walk is always filled with significant phenomena, which are valuable to see and to feel" (2012, p. 165). Yap shows that through flânerie, one can treasure valuable moments with their loved ones.

\footnotetext{
May walked briskly to her son. "Come," she said linking her arm through his, "let's take a walk. I am sure Ruth would appreciate some time with Libby. They have had hardly any time together since we arrived."

(Yap 2018, p. 296)
}

According to Coverley (2012, p.102), William Gilpin was the first theorist to develop a method to view our environment in the context of travelling. A brave traveller will be sent to the British countryside to engage with the wilderness and untamed landscapes. This concept has developed and changed the mindset in the late eighteenth century in a way that the concept transforms their understanding of British geographical landscape and its rural topography. Since then, walking in nature and the engagement that the walker makes with the wilderness capture what Coverley claims, "the literal sense of being on foot." When May and her family move to England, May finds it difficult for her to adapt to changes in terms of adjusting to new surroundings and negotiating social interaction with other city inhabitants. This situations has been represented in the excerpt below:

May spotted the empty bench and immediately hurried towards it with Lin skipping by her side. All round them, people were settling down on grassy banks or on benches to take in the sun. She guessed that the bench was empty because it was under the shade of a silver maple. Hugh would have pulled her leg for seeking out the shade. Everyone else seemed to be making for the sunniest spot they could find.

(Yap 2018, p. 349) 
Being in a tropical country like Malaysia, May feels uneasy about the heat and sunny weather that she continues to react the same way with the natural weather in England. However, this has allowed her to observe the surroundings and the city inhabitants in a new place. Yap's flâneuse enjoys the freedom to observe others while remaining aloof from the crowd in the park.

She sat on the bench, one arm stretched out along its back, the other still holding on to the basket. A
flock of pigeons landed in front of her, tempted by the crumbs of food on the ground. She watched them
peck, their tiny heads bobbing up and down. She thought of her new life in England. It was so different
from that in Malaya. Even the air smells different.
(Yap 2018, p. 350)

England's park has also been depicted as a city full of pigeons, a permanent fixture in the western urban landscapes, a stark contrast to Malaya's tropical conditions. In a study conducted by Jiguet et al. (2019), urban environments provide a suitable habitat for these city birds to live and adapt. According to the research, cities' environmental conditions, including land cover, human density, organicity, noise, and air pollutions shape the variance and numbers of urban pigeons' mutilation. Bryce's (2018) study reaches similar agreement; the rocky surroundings in the city provide a suitable habitat for them to become a part of permanent city inhabitants. Meanwhile, Cai and Calisi (2016) also mention that urban pigeons are the mirror to urban environmental conditions that their existence in the city is linked to human activities. Yap's flâneuse welcomes these native city dwellers through her eyes that she observes rather intensely while allowing herself to experience London's air and scents. However, London is seen as a lonely place for May. The unwanted gaze and treatment that she receives with the female Londoners are not very welcoming to a newcomer like her.

The playground was crowded. There were children playing, young mothers chatting and grandmothers
knitting. It was literally a whole community of women of all ages charged with minding kids. She saw
a bench and went to it. "May I?" she asked of the two women seated there. They nodded and returned
to their chatter, cigarettes in hand. May perched herself at the seat's corner. She was conscious of being
alone in a crowd. Ruth had told her that London could be a very lonely place, revealing bits of her
previous life when she was with Mark. May agreed. She stared at the women around her and wondered
if the person who had shouted abuse at Ruth was among them. She had not suffered racial discrimination
like Ruth. Neither Craig nor Lin looked typically oriental. Their light complexion and hair helped and
she would probably be mistaken as their nanny.
(Yap 2018, p. 351)

In Malaya, May is well-known, but in London, she feels alienated by groups of women in the park, being wary of any unwanted discussions that might involve sensitive issues. A similar situation happens when May and her daughter travel to the British countryside to visit Ruth. They appeared to invite a strange gaze from the locals as they walk down the rural streets.

They walked up the High Street. People stared at them discreetly, dropping their eyes when she stared back at them. Unabashed, May smiled holding Lin's little hand firmly in hers. (Yap, 2018, p. 358)

The flâneuse in Yap's historical narration could warrant the independence and the visibility that afford western flâneuse. Yap's character, however, is still being confined to conventional treatment of a flâneuse that Wolff (1985) describes; May is defined by her social status and her links to social deviants located both in Malaya and England. That is, her connection to the urban landscape and domestic consumption defines her compliance to traditional roles that existed in Malayan context. On the one hand, May's depiction is considered parallel to the convention of the visible flâneuse where she could walk freely in the urban street, fulfilling her own needs outside her private spaces. On the other hand, her ability to access the public sphere is still defined by her gender and social class, given her husband's social (and luxury) status; she is a wife to a well-known British officer. May's closer attachment to public spaces in Malaya than her emotional displacement in England is perceived 
as central to the description of "home". Being distant from the crowd but a part of the crowd, the public domain in Malaya becomes home to May Anderson, but in England, it is merely a place to dwell on the space that does not provide psychological sanctuary to her. Esmaeil (2019) mentioned that although significant attention has been given to women focusing on their traditional roles as mothers, sisters and faithful homemakers in the literature related to the war, yet women writers in today's world are breaking these exclusive grips that men owned in the literary production (p. 115). By focusing on Where the Sunrise is Red, the context that is characterised by colonisation has allowed women like May to carry out both traditional and modern duties in private and public spaces.

\section{CONCLUSION}

From Kuala Lumpur to Port Dickson, to London and Somerset, a woman cannot walk in the urban and rural landscape the way a man can. In this novel, Yap foregrounds her protagonist, who occupies a male-dominant public space. If we have become so accustomed to the role of men in the public sphere that we hardly notice, in this paper, we have highlighted that women too are involved, and they highlight the values inherent within rural and urban spaces. This study presents a new way of reading historical fiction through Elkin's concept of flâneuse, female flâneur, in the tropical colonised Malaya and colonial England. The public sphere undoubtedly is a significant literary device to establish the visibility of flâneuse in Malaya and England. Yap's protagonist is associated with the public domain, both literally and symbolically. It has become a dominant theme of identity reconstruction and a sense of belonging. In addition, its capability to become a place of isolation for a flâneuse, the public sphere is also seen as "home" with infinite boundaries. In other words, the public domain has turned to be a place where women can also seek refuge, feel at home and visibly connected. In this Asian context, Baudelaire's flâneur has been reconstructed that takes on a new meaning. The classic tropical depiction of Malaya subtly confounds Baudelaire's ideal types of the flâneur as this literary figure emerges in the Asian country as a subject who continually strives for a recognisable cultural tradition.

\section{REFERENCES}

Bautista, A. A. (2017). A Flâneur in the erotic city: Prince and the urban imaginary. J Afr Am St. 21, $353-372$.

Boutin, A. (2012). Rethinking the flâneur: Flânerie and the senses. Journal of the Society of Dix Neuxiémistes. 16(2), 124-132.

Brand, D. (1991). The spectator and the city in nineteenth-century American literature. Cambridge: Cambridge UP.

Bryce, E. (2018). Why are they so many pigeons? Live Science. Retrieved February 15, 2020 from https://www.livescience.com/63923-why-cities-have-so-many-pigeons.html

Cai, F. \& Calisi, R.M. (2016). Seasons and neighbourhoods of high lead toxicity in New York city: the feral pigeon as a bioindicator. Chemosphere. 161, 274-279.

Ceuterick, M. (2020). Walking, haunting, and affirmative aesthetics: the case of women without men. Aniki. 7(1), 96-114.

Coverley, M. (2012). The art of wandering: the writer as walker. Harpenden: Oldcastle Books.

Chaudhury, S. \& Lundberg, A. (2018). Tropical flânerie and the creative Asian city: a perambulation of literature. Living Cities: Tropical Imaginaries. 17(1), 74-89.

Dwyarie, R.D. \& Tjahjani, J. (2019). Intercultural concepts in place cliché by Jacques Godbout. 3L: The Southeast Asian Journal of English Language Studies. 23(3), 137-149.

Elkin, L. (2016). Flâneuse: women walk the city in Paris, New York, Tokyo, Venice and London. London: Penguin Random House.

Esmaeil, Z. (2019). Ecriture feminine: feminism and nationalism in Seyyedeh Zahra Hosseini's 'One woman's war: da’. 3L: The Southeast Asian Journal of English Language Studies. 25(3), 115-125. 
Hahn, J. (2014). From lonely to loony flâneur? The sarakmap in contemporary Hindi literature. Studien zur Indologie und Südasienstudien. 31, 1-25.

Jiguet, F., et al. (2019). Urban pigeons losing toes due to human activities. Biological Conversation, 240, 108241

Ke Wang \& Rui Shang. (2019). Study on The Reshaping Form and Function of Urban Culture to Modern Urban Space. Paper presented the Asia International Symposium on Arts, Literature, Language and Culture (AISALLC 2019). pp. 409-414.

King, R. (2008). Kuala Lumpur and Putrajaya: Negotiating urban space in Malaysia. Singapore: NUS Press Singapore.

Lucas, R. (2004). Inscribing the city: A flâneur in Tokyo. Anthropology Matters Journal. 6(1), Retrieved March, 182020 from https://www.anthropologymatters.com/index.php/anth_matters/article/view/110/217

Miller, H. (1982). Prince and premier: A biography of Tunku Abdul Rahman Putra. Petaling Jaya: Eastern Universities Press (M) Sdn. Bhd.

Mohamad, M. (2002). "From nationalism to post-developmentalism: The intersection of gender, race and religion in Malaysia," Macalester International. 12(12).

Nicholson, G. (2010). The lost art of walking: The history, science, philosophy, literature, theory and practice of pedestrianism. Essex: Harbour.

Răşcanu, I. (2018). The status of women between 'tradition' and 'modernity' in Chitra Banerjee Divakaruni's Oleander Girl. Synergy. 14(2), 221-234.

Richardson, T. (Ed.). (2015). Walking inside Out: Contemporary British Psychogeography. London: Rowman \& Littlefield International.

Rizal, Y. (2014). The British legacy and the development of politics in Malaya. Global Journal of Human-Social Science: D History Archaeology \& Anthropology. 14(1), 55-66.

Ruzy, S. H. \& Fatin, N. S. F. (2016). Psychogeography of Kuala Lumpur in Nassury Ibrahim's selected poems. Malay Literature. 29 (2).

Sundareson, S. (2014). Walk down memory lane of the historical district. The News Straits Times. Retrieved February 16, 2020 from https://www.nst.com.my/news/2015/09/walk-down-memory-lane-historicaldistrict

Sayyed, R.M. \& Tayyebeh, B. Y. (2018). New norms. Continental Philosophy Review. 38, 199-222.

Tan Twan Eng. (2012). The Garden of Evening Mists. Edinburgh: Myrmidon.

Uma, R. A. R. V. \& How, C. (2019). Symbolic representation of Tun Dr Mahathir: Visual analysis of a Malaysian short film. 3L: The Southeast Asian Journal of English Language Studies. 25(4), 138-155.

Wolff, J. (1985). The invisible flâneuse: women and the literature of modernity. Theory, Culture and Society. 2(3), 37-46.

Yap, C. L. (2018). Where the sunrise is red. Singapore: Marshall Cavendish International (Asia) Pte Ltd.

Yao, S. (2016). The Malayan Emergency: A small, distant war. Copenhagen: Nordic Institute of Asian Studies.

Zohreh, R. \& Seyyed, M. M. (2014). History/ fiction: An intertextual reading of E. L. Doctorow's Ragtime. 3L: The Southeast Asian Journal of English Language Studies. 20(1),157-166. 